\title{
FOREST DIVERSITY AND CARBON SEQUESTRATION IN RESUNGA SACRED GROVE, GULMI, NEPAL
}

\section{BHUVAN KESHAR SHARMA ${ }^{1} \bowtie$, CHANDRA PRASAD POKHAREL ${ }^{2}$ AND LAXMI JOSHI SHRESTHA ${ }^{3}$}

\author{
${ }^{1}$ Conservation Development Foundation, Koteswar, Kathmandu, Nepal \\ ${ }^{2}$ Central Department of Botany, Tribhuvan University, Kathmandu, Nepal \\ ${ }^{3}$ Department of Botany, Amrit Campus, Tribhuvan University, Kathmandu, Nepal \\ bhuvan_keshars@hotmail.com
}

\section{ABSTRACT}

Resunga forest is a store-house of diverse wildlife and wild plants ranging from sub-tropical to temperate climatic zones in the midhill physiographic region. Aiming to assess the forest diversity and sequestrated carbon, this study was conducted in Resunga religious forest. Data were collected from systematically distributed plots at the interval of $50 \mathrm{~m}$ elevation along the altitudinal gradients from $2100-2450 \mathrm{~m}$ elevation. Eight circular plots of $10 \mathrm{~m}$ radius were used to collect information on tree level characteristics. Importance value index, Shannon-Weiner index of diversity and evenness were used to assess the forest diversity. Published allometric functions were used to examine the aboveground tree biomass. Tree carbon stocks were calculated using carbon fraction value. Nineteen tree species were recorded from Rhododendron and oak forests. Comparing the forest types, Rhododendron forest was more diverse $(H=1.0)$ than oak forest $(H=0.9)$. Similarly, tree species were more evenly distributed $(0.87)$ in the oak forest than that of $R$ hododendron forest (0.77). The vegetation carbon stock of Rhododendron forest was lower (101.8 t/ha) than that of oak forest (153.8 t/ha). Overall, the average vegetation carbon stocks in the Resunga Sacred Grove (RSG) was $127.75 \mathrm{t} / \mathrm{ha}$.

Keywords: importance value, Shannon-Weiner diversity index, evenness, aboveground tree biomass

\section{INTRODUCTION}

Biological diversity is the variability among living organisms in a given ecological complex (Aerts et al., 2006) and is important to maintain the health of ecosystems and long-term survival of the human (Boyd \& Banzhaf, 2007). There are three interrelated and distinct levels of biodiversity namely species, genetic, and ecosystem (Melchias, 2001; Aerts et al., 2006). Biodiversity can be further categorized on the basis of the space used by the different components as alpha, beta, and gamma diversity (Harrison \& Inouye, 2002; HMGN/MoFSC, 2002; GoN/MoFSC, 2014). Forest have important role for the conservation of biodiversity and other ecosystem services as to prevent soil erosion, provide water for irrigation and drinking, food and maintain wood supply (Boyd \& Banzhaf, 2007).

Sacred groves or religious forest are forest patches having traditions and cultural values of 
local and indigenous people who protect the groves with their strong socio-religious beliefs and taboos (Khumbongmayum et al., 2006). Sacred groves have received considerable attention, as a pioneer of community managed natural resource management regime in Nepal.

Resunga forest is situated in the Gulmi district and covers an area of 3400 ha between 5602300 m elevations (Khadka \& Pokharel, 1999; Acharya, 2012). Resunga is the mountains with historical, religious, cultural, touristic, environmental and archeological value. Besides forest products about 252 watersheds have been estimated in the Resunga area; which is the main source of drinking water for local people (Panthi, 1984). The forest resources are being traditionally used for timber, fodder, fuel wood, leaf litter, and medicinal plants (Khadka \& Pokharel, 1999). Surrounded by eleven Village Development Committees (VDCs), Resunga is not only considered as a religious spot but also as historical pilgrimage, watershed, sources of biological diversity, in-country tourism destination, splendid recreation place with full of greenery (Panthi, 1984; Khadka \& Pokharel, 1999; Acharya, 2012).

Resunga, a hill of amazing geographical setting and fascinating beauty, is rich in biodiversity. It is a store-house of diverse wild animal and plants ranging habituate in sub-tropical and temperate forests. Out of 3400 ha forest land of Resunga, 1973.93 ha is covered by eighteen community forests, 165.17 ha is covered by religious forest (sacred grove) and the remaining area is under government managed (DFO, 2014). The plant species available in this area are Pinus roxburghii, Alnus nepalensis, Schima wallichii and Rhododendron arboreum. Though the region is rich in plant diversity but due to anthropogenic disturbances some of the species are in state of extinction (DFO, 2014). This forest provides favorable habitats for wild animals like Common leopard (Panthera pardus), Barking deer (Muntiacus muntjak), Ghoral (Naemorhedus goral), Jungle cat (Felis chaus), Indian crested porcupine (Hystrix indica) and Hanuman langur (Semnopithecus entellus) (Pandey \& Chalise, 2014). Once common large scavenging mammal, Himalayan black bear (Ursus thibetanus), is now extinct from this forest (DFO, 2014). The historical pond situated in this range also provides the suitable habitats for birds like Red jungle fowl (Gallus gallus), Spotted dove (Streptopelia chinensis), Indian nightjar (Caprimulgus asiaticus) and Parakeet (Psittacula sp.). The present study aims to assess the forest diversity and estimate the vegetation carbon stock of Resunga sacred grove (RSG) which will be a good basis to the incentive provisioned for Reducing Emission from Deforestation and Forest Degradation (REDD) mechanism.

\section{MATERIALS AND METHODS}

Present study was carried out in the religious forest area of Resunga hill which covers an area of about 165.17 ha (fig. 1). The altitude of the study site varies from $2000 \mathrm{~m}$ to 2600 masl (Subedi, 1998; DFO, 2014). The forest is rich in biodiversity with great variation in flora accompanied by sub-tropical and temperate forests encompassing floral species like Schima wallichii, Castanopsis indica, Pinus roxburghii, Quercus semecarpifolia, Rhododendron arboreum, Pyrus pashia, Aesculus indica, Pinus roxburghi, Myrsine semiserrata (Khadka \& Pokhrel, 1999). The climatic condition of the study site is of cool and humid type of temperate climate. The average maximum and minimum temperatures of $R S G$ are $26^{\circ} \mathrm{C}$ and $6^{\circ} \mathrm{C}$ respectively with the average annual rainfall of $1,900 \mathrm{~mm}$ (Pandey \& Chalise, 2014). 


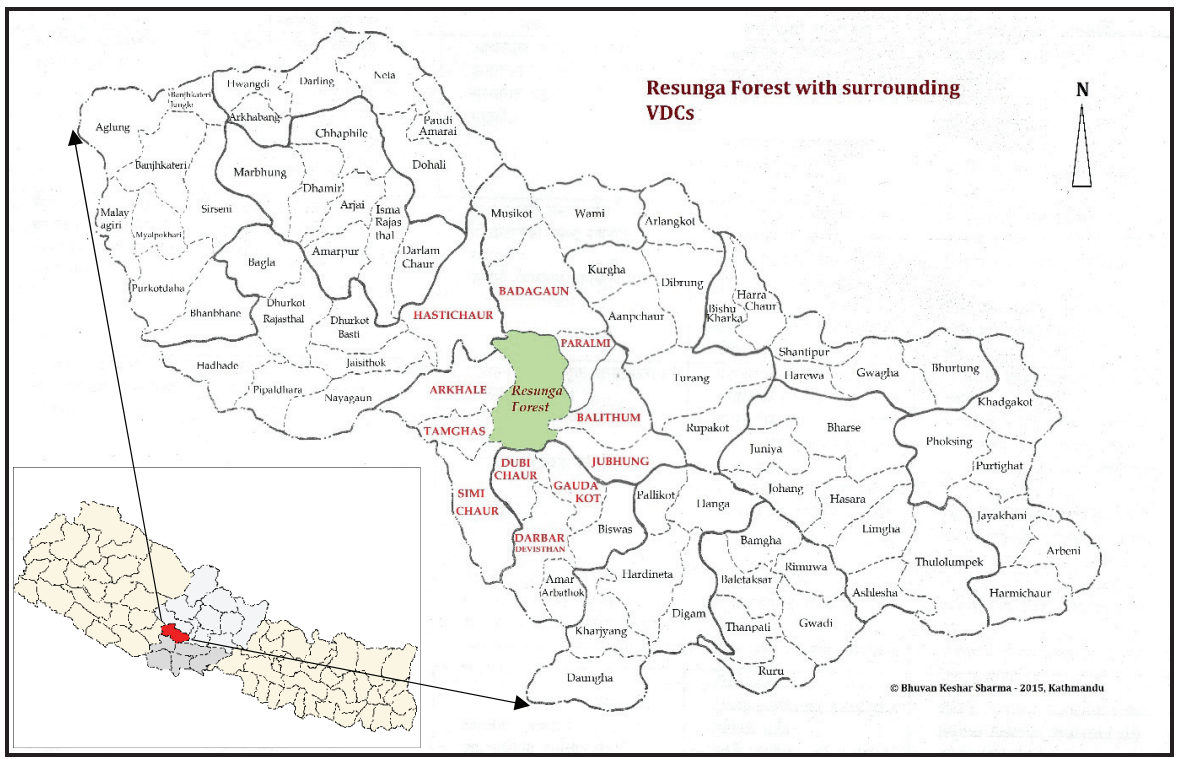

FIG. 1. Map of Gulmi district with study area and surrounding VDCs.

\section{Forest diversity}

Circular plots having $10 \mathrm{~m}$ radius were used to conduct forest inventory (Yadhav et al., 2013). Total numbers of surveyed plots in RSG were 8 and distributed between $2100 \mathrm{~m}$ to 2450 $\mathrm{m}$ elevation. Plots were systematically distributed in transect prepared along the altitudinal gradients at the interval of 50 m between 2100-2450 m elevation. Similarly, local name, scientific name, DBH and height of trees were also collected. The specific results were determined by applying following formulae (Zobel et al., 1987; Sharma et al., 2012).

IV = Relative density + Relative diversity + Relative dominance

Where,

$$
\begin{aligned}
& \text { Relatives frequency }=\frac{\text { Frequency of species } i}{\text { Sum of frequencies of all species }} * 100 \\
& \text { Relatives density }=\frac{\text { Density of species } i}{\text { Sum of density of all species }}{ }^{*} 100
\end{aligned}
$$$$
\text { Relatives dominance }=\frac{\text { Dominance of species } i}{\text { Sum of dominance of all species }} * 100
$$ 
Name of each forest type was determined by ordering the Importance values of each tree species recorded (Shrestha et al., 2015). Considering the physical attribute as morphological diversity tree height were measured by using Vertex IV and Transponder T3. Crown coverage of tree species were measured by using densiometer. On the basis of tree height, trees were further classified in three categories (Sharma, 2014). Tree with less than $10 \mathrm{~m}$ height were considered as small, $10-15 \mathrm{~m}$ height were considered as medium and more than $15 \mathrm{~m}$ height were considered as larger (Sharma, 2014).

Shannon-Weiner index of diversity was utilized to calculate tree diversity. Evenness was calculated by dividing Shannon-Weiner diversity index with the log value of total number of species found in the area (Mueller-Dombois \& Ellenberg, 1974; Zobel et al., 1987; Yadhav et al., 2013; Shrestha et al., 2015):

Where,

$$
\mathrm{H}=-\sum_{\mathrm{i}=1}^{\mathrm{s}}(\mathrm{pi})(\log \mathrm{pi})
$$

$$
\begin{aligned}
& \mathrm{H}=\text { Shannon-Weiner index of species diversity } \\
& \mathrm{Pi}=\text { Proportion of total number of individual of species } \mathrm{i} \\
& \mathrm{S}=\text { Number of species }
\end{aligned}
$$

\section{Carbon sequestration}

The above ground biomass of trees was calculated using published allometric functions developed by Chave et al. (2005). The climate of the study areas was moist, with 1500-4000

\begin{tabular}{|c|c|c|}
\hline \multicolumn{3}{|c|}{ AGTB $=0.0509 \rho D^{2} \mathrm{H}$} \\
\hline Where, & & \\
\hline AGTB & $=$ & above ground tree biomass $(\mathrm{kg})$ \\
\hline$\rho$ & $=$ & wood specific gravity $\left(\mathrm{g} \mathrm{cm}^{-3}\right)$ \\
\hline $\mathrm{D}$ & $=$ & tree diameter at breast height $(\mathrm{cm})$ \\
\hline $\mathrm{H}$ & $=$ & tree height $(\mathrm{m})$ \\
\hline
\end{tabular}
$\mathrm{mm}$ of annual rainfall and tropical evergreen to sub-tropical forests, the allometric equation developed by Chave et al. (2005) was appropriate to use for the above ground tree biomass analysis (AGTB).

The wood specific gravity was extracted from published literatures (Sharma \& Pukkala, 1990; Zanne et al., 2009). The biomass stock density (in $\mathrm{kg} \mathrm{m}^{-2}$ ) was calculated by summing up of individual weights (in $\mathrm{kg}$ ) of a sampling area and dividing it by total sampled area. The value was converted to ton $\mathrm{ha}^{-1}$ by multiplying it by 10 (GoN, 2011). The biomass stock densities were converted to carbon stock densities (weight of carbon in the tree) by using the IPCC (2006) carbon fraction of 0.47 . Root-to-shoot ratio value of $1: 5$ (20\% of AGTB) was used to find below ground biomass (MacDicken, 1997). Total carbon stock density of tree in particular vegetation was calculated by summing up above ground and below ground carbon stock density of tree (Sharma et al., 2014). 


\section{RESULTS AND DISCUSSION}

Almost all land use type of RSG was forest. Based on topographic and LRMP land utilization maps, land use pattern of RSG are disaggregated (LRMP, 1986). Dominant land use type of RSG is forest and areas under other landuse categories are almost negligible.

\section{Forest diversity}

Based on the Importance Value Index (IVI) of canopy (pole and tree) species, forest areas of RSG were further classified into two types, Rhododendron and oak. The most important plant species in the canopy layer of Rhododendron forest was Rhododendron arboreum (IVI = 68.4) followed by Lyonia ovalifolia (IVI $=57.0$ ) and Schima wallichii (IVI $=35.8$ ) respectively. In the oak forest, Quercus semicarpifolia was more important tree species with higher IVI (80.6) followed by Rhododendron arboreum (IVI = 73.2). Based on the important value, the other important tree species found in this forest were Myrsine semiserrata (IVI = 21.9), Ilex dipyrena (IVI = 20.5), Ilex sp (IVI = 17.7) and Benthamidia capitata (IVI = 17.2) respectively (Annex 1). LRMP (1986) categorized the forest area of RSG as Tropical Mixed Hardwood with more than $75 \%$ species mixed with hardwood species and Pinus roxburghii forest either with its pure stand or mixing with other broad leaved species.

The crown coverage of the Rhododendron and oak forests of RSG were $93 \%$ and $85 \%$ respectively. In the Rhododendron forest, the maximum height of the tree was $38 \mathrm{~m}$ (Schima wallichii) and the maximum DBH was $116.2 \mathrm{~cm}$ (Rhododendron arboreum). Similarly, the average tree height of this forest was $14.6 \pm 7.6 \mathrm{~m}$ with $24.9 \pm 18.1 \mathrm{~cm}$ of average DBH. In the oak forest, Myrsine semiserrata was the tallest tree $(25 \mathrm{~m})$ and Quercus semicarpifolia hasthe maximum DBH $(88 \mathrm{~cm})$ (fig. 2). The average tree height and DBH of this forest were $11.5 \pm 4.6$ $\mathrm{m}$ and $26.8 \pm 15.7 \mathrm{~cm}$ respectively (table 1 ). As per LRMP (1986) data the crown density of this forest was between $40-70 \%$ having immature or small timber size materials.

The general ecological principle in the open canopy forest, stem per unit area is highest due to having more light in the ground (Shrestha et al., 2015). In this study, forest canopy coverage in Rhododendron forest was higher but the density was less, where as in oak forest the canopy coverage is lower and density was higher. The forest is protected due to religious belief and distant from the settlement, there is fewer disturbances from anthropogenic activities. This result also matches with the general ecological principle (Sharma, 2003). Similar result was recorded in other study conducted in the sacred groves Kathmandu valley (Shrestha et al., 2015). The altitude and the physiographic condition of this study site also help to conserve the current land use.

The result showed that 21 tree species (including 2 species of shrub) were recorded from the RSG. In Rhododendron forest, 13 tree species were recorded with the density of 318 tree/ ha. The number of recorded tree species from oak forest was 15 with 599 tree/ha. 7 common tree species namely Rhododendron arboreum, Quercus lanata, Pyrus pashia, Persea duthiei, Myrsine semiserrata, Lyonia ovalifolia and Ilex sp. were common in both the forest types. The similarity index showed that more than $50 \%$ of tree species were found to be similar between these forests. The calculated values of Shannon-Weiner species diversity index were 1.0 and 0.9 for Rhododendron and oak forests respectively. This indicated that Rhododendron forest is 
most diverse than oak forest in term of tree diversity. Evenness value indicated that tree species of oak forest $(0.87)$ were more evenly distributed than that of Rhododendron forest $(0.77)$.

TABLE 1. Tree characteristics and other parameters assessed in the RSG.

\begin{tabular}{|c|l|c|c|}
\hline SN & Characteristics / parameters & Rhododendron forest & Oak forest \\
\hline 1 & Number of species & 13 & 15 \\
\hline 2 & Shannon-Weiner diversity index & 1.0 & 0.9 \\
\hline 3 & Evenness & 0.77 & 0.87 \\
\hline 4 & Average height of tree (m) & $14.6 \pm 7.6$ & $11.5 \pm 4.6$ \\
\hline 5 & Average DBH (cm) & $24.9 \pm 18.1$ & $26.8 \pm 15.7$ \\
\hline 6 & Area covered (\%) & 38 & 62 \\
\hline 7 & Tree density (number ha-1) & 318 & $2000-2600$ \\
\hline 8 & Altitudinal ranges (m) & $1800-2150$ & \\
\hline 9 & Similarity index & & \\
\hline
\end{tabular}

On the basis of the tree height, RSG was dominated from the small sized trees (63\%). The representations of medium and large sized tree in this forest were $26 \%$ and $11 \%$ respectively. Among the 443 small size tree species of Nepal (Sharma, 2014), 12 of them were recorded from RSG. Similarly, out of 152 medium sized tree and 116 large sized tree species of Nepal (Sharma, 2014) only 5 and 2 respective tree species were recorded from RSG (table 2).

TABLE 2. Tree size and their representation in RSG.

\begin{tabular}{|c|l|c|c|}
\hline SN & Tree height & Number of species & Representation (\%) \\
\hline 1 & Large & 2 & 11 \\
\hline 2 & Medium & 5 & 26 \\
\hline 3 & Small & 12 & 63 \\
\hline
\end{tabular}

\section{Carbon sequestration}

Average carbon stock in the forest trees of RSG was $127.75 \mathrm{t} / \mathrm{ha}$. The carbon stock of Rhododendron forest was lower (101.8 t/ha) than that of oak forest (153.8 t/ha) (fig. 2). In Rhododendron forest higher amount of carbon was confiscated by Rhododendron arboreum (38.8 t/ha) followed by Schima wallichii (21.8 t/ha) and Lyonia ovalifolia (17.6 t/ha) respectively. In this forest Ilex sp shared the lowest amount of carbon stock ( $0.1 \mathrm{t} / \mathrm{ha})$. In the oak forest higher amount of carbon was confiscated by Rhododendron arboreum (66.4 t/ha) followed by Quercus semicarpifolia (53.2 t/ha) and Myrsine semiserrata (8.4 t/ha) respectively. In this forest, Rhus succedanea shared the lowest amount of carbon stock (0.2 t/ha) (Annex 1). Resembling with the finding of this study, there is positive relationship between biodiversity and carbon stock 
in biodiversity hotspot areas (Midgley et al., 2002). The similar result was reported from the forest of low land Tarai region of Nepal (Mandal et al., 2013). The significant relations between the tree species richness and carbon sequestration was also reported from studies conducted in other sacred groves of Nepal (Shrestha et al., 2015).

The sequestrated carbon in the forest varied according to the forest type and stem density. Species composition of the forest also differ the average amount of assimilated carbon in the particular forest type. In the study area Rhododendron arboretum (66.4 t/ha) was highest carbon sequestrating tree species. The difference found in the forest category and carbon stocks in these studies were due to difference in physiographic region and wood density of tree species.

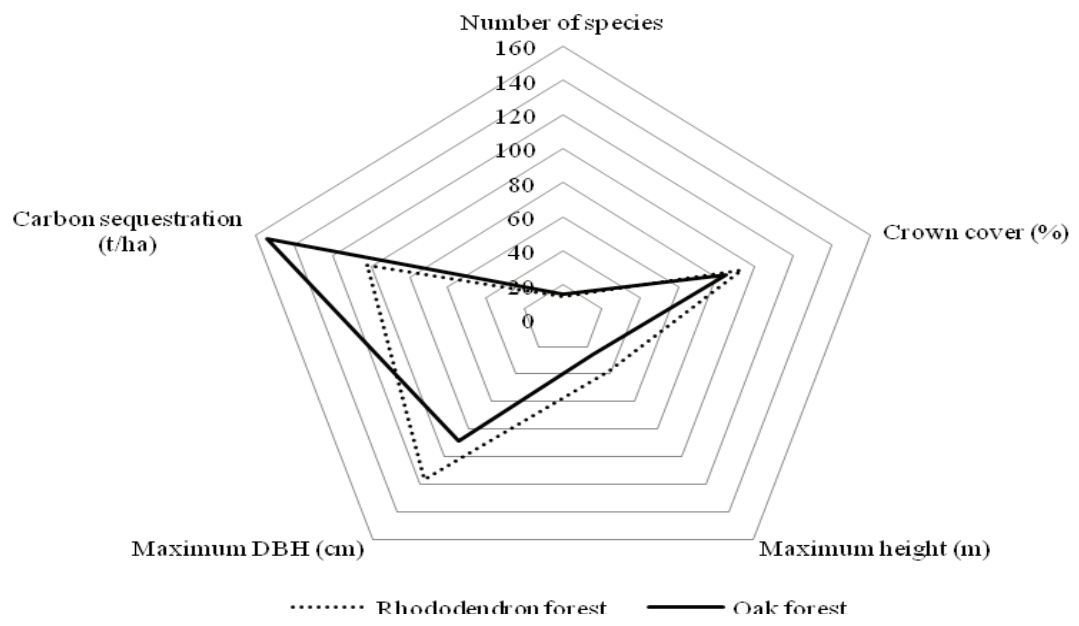

FIG. 2. Forest and tree characteristics of Resunga religious forest.

In RSG 21 species of tree, including two species of shrub, were distributed in two different types of forests, Rhododendron and oak. Seven tree species were common in both of the forests. RSG was dominated from the small sized tree $(n=12)$. Average carbon stock was $127.75 \mathrm{t} /$ ha in RSG. The carbon stock in the trees of Rhododendron forest was lower (101.8 t/ha) than that of oak forest (153.8 t/ha). The determinant factors for the carbon stock in the RSG were species richness and wood density of the tree species.

\section{ACKNOWLEDGEMENTS}

District Forest Office, Gulmi is acknowledged for providing research permission. Local Resource Persons Ms. Dhruba Bhandari, Mr. Roshan Singh Thakuri and Mr. Arjun Pokharel are acknowledged for providing valuable information and assisting for the field work. Mr. Deepak Pandit - DFO office of Gulmi for sharing experiences. 


\section{REFERENCES}

ACHARYA, R (2012) Study of medicinal plants of Resunga hill used by Magar community of Badagaun VDC, Gulmi district, Nepal. Scientific World 10 (10): 54-64.

AERTS, R; OVERTVELD, K V; HAILE, M; HERMY, M; DECKERS, J; MUYS, B (2006) Species composition and diversity of small Afromontane forest fragments in northern Ethiopia. Springer Science 187:127-142.

BOYD, J; BANZHAF, S (2007) What are ecosystem services? The need for standardized environmental accounting units. Ecological Economics 63:616-626.

CHAVE, J; ANDALO, C; BROWN, S; CAIRNS, MA; CHAMBERS, J Q; EAMUS, D; FÖLSTER, H; FROMARD, F; HIGUCHI, N; KIRA, T; LESCURE, J P; NELSON, B; OGAWA, H; PUIG, H; RIÉRA, B; YAMAKURA, T (2005) Tree allometry and improved estimation of carbon stocks and balance in tropical forests. Oecologia 145: 87-99.

DFO (2014) Monitoring and evaluation report of Community Forest Users' Group. District Forest Office (DFO), Gulmi, Nepal; 89 pp.

GoN (2011) Forest carbon assessment procedure. Ministry of Forest and Soil Conservation, REDD Forestry and Climate Change Unit, Nepal; 72 pp (In Nepali).

GoN/MoFSC (2014) Nepal biodiversity strategy and action plan (2014 - 2020) Government of Nepal, Ministry of Forest and Soil Conservation, Kathmandu, Nepal; 232 pp.

HARRISON, S; INOUYE, B D (2002) High $\beta$ diversity in the flora of Californian serpentine 'islands'. Biodiversity and Conservation 11:1869-1876.

HMGN/MoFSC (2002) Nepal biodiversity strategy. His Majesty the Government of Nepal, Ministry of Forest and Soil Conservation, Kathmandu, Nepal; 117 pp.

IPCC (2006) Guidelines for national greenhouse gas inventories: agriculture, forestry and other land use. Intergovernmental Panel on Climate Change 4: 4.12-4.83.

KHADKA, U R; POKHAREL, C P (1999) Studies on vegetation composition and resources use pattern in Resunga (Gulmi). A report submitted to the University Grants Commission, Kathmandu, Nepal; 23 pp.

KHUMBONGMAYUM, A D; KHAN, M L; TRIPATHI, R S (2006) Biodiversity conservation in sacred groves of Manipur, northeast India, population structure and regeneration status of woody species. Biodiversity and Conservation 15: 2439-2456.

LRMP (1986) Land utilization report. Land Resource Mapping Project (LRMP), Kenting Earth Science Limited. Kathmandu: His Majesty's Government of Nepal and Government of Canada.

MACDICKEN, K G (1997) A guide to monitoring carbon storage in forestry and agro-forestry projects. Winrock International, Institute for Agricultural Development.

MELCHIAS, G (2001) Biodiversity and conservation. Science Publishers, Inc., Enfield, New Hampshire.

MIDGLEY, G; HANNAH, L; MILLAR, D; RUTHERFORD, M C; POWRIE, L W (2002) Assessing the vulnerability of species richness to anthropogenic climate change in a biodiversity hotspot. Global Ecology and Biogeography 11:445-451.

MUELLER-DOMBOIS, D; ELLENBERG, H (1974) Aims and methods of vegetation ecology. John Wiley and Sons, Inc.

PANDEY, D; CHALISE, M K (2014) Diversity in mammalian fauna in Resunga forest, Gulmi, Nepal. In 
PANTHI, P (1984) Introduction of Resunga (Resunga sambandhi chinari). District forest office, Gulmi, Nepal; 95 pp (In Nepali).

SHARMA, P D (2003) Ecology and environment. Rastogi Publications, India; 660 pp.

SHARMA, B K (2014) Bioresources of Nepal. Subidhya Sharma, Kathmandu, Nepal; 819 pp.

SHARMA, B K; CHALISE, M K; SOLANKI, G S (2012) Vegetation types and wildlife occurrence in Baghmara Buffer Zone Community Forest, Nepal. International Multidisciplinary Research Journal 2 (2):52-65.

SHARMA, B K; SOLANKI, G S; CHALISE, M K (2014) Carbon sequestration in a community managed forest of Chitwan National Park's buffer zone at central lowland Nepal. Bio journal 9(1): 46-54.

SHARMA, E R; PUKKALA, T (1990) Volume equations and biomass prediction of forest trees of Nepal. Forest Survey and Statistics Division, Ministry of Forest and Soil Conservation. Kathmandu, Nepal.

SHRESTHA, L J; DEVKOTA, M; SHARMA, B K (2015) Phyto-sociological assessment of sacred groves in Kathmandu Nepal. International Journal of Plant and Soil Science 4 (5): 437-444.

SUBEDI, R R (1998) Historical glimpse of Gulmi. Kiran Pustakalaya, Tamghas, Gulmi, Nepal.

YADHAV, B R; DUTTA, I C; CHALISE, M K; WILLIUMS, C; SHARMA, B K (2013) Habitat utilization by Asiatic wild elephant (Elephus maximus) in Parsa Wildlife Reserve, Nepal. ECOPRINT 20: 41-52.

ZANNE, A E; LOPEZ-GONZALEZ, G; COOMES, D A; JANSEN, ILIC, J; JANSEN, S; LEWIS, S L; MILLER, R B; SWENSON N G; WIEMANN, M C; CHAVE, J (2009) Global wood density database. Dryad. Identifier: http://hdl.handle.net/10255/dryad.235.

ZOBEL, D B; BEHAN, M J; JHA, P K; YADAV, U K R (1987) A practical manual for ecology. Ratna Book Distributors, Kathmandu, Nepal. 
ANNEX 1. Tree species, importance value, forest types and sequestered carbon in RSG.

\begin{tabular}{|c|l|c|c|c|c|l|}
\hline \multirow{2}{*}{ SN } & \multirow{2}{*}{ Species } & \multicolumn{2}{|c|}{ Rhododendron forest } & \multicolumn{2}{|c|}{ Oak forest } & \multirow{2}{*}{ Tree } \\
\cline { 2 - 6 } & IV & $\begin{array}{c}\text { Carbon } \\
\text { stock t/ha }\end{array}$ & IV & $\begin{array}{c}\text { Carbon } \\
\text { stock t/ha }\end{array}$ & \\
\hline 1 & Benthamidia capitata & -- & -- & 8.6 & 2.1 & Small \\
\hline 2 & Castanopsis indica & 7.05 & 3.3 & -- & -- & Medium \\
\hline 3 & Cinnamomum glaucescens & -- & -- & 4.7 & 0.7 & Medium \\
\hline 4 & Engelhardia spicata & 4.65 & 1.1 & -- & -- & Small \\
\hline 5 & Eurya acuminata & 39.25 & 3.5 & -- & -- & Small \\
\hline 6 & Ilex dipyrena & -- & -- & 23.65 & 5.5 & Small \\
\hline 7 & Ilex sp. & 17.1 & 0.1 & 8.85 & 1.4 & Small \\
\hline 8 & Lindera pulcherrima & -- & -- & 14.8 & 0.3 & Small \\
\hline 9 & Luculia gratissima & -- & -- & 2.55 & 0.7 & Shrub \\
\hline 10 & Lyonia ovalifolia & 28.5 & 17.6 & 5.55 & 1.8 & Medium \\
\hline 11 & Myrica esculenta & 32.8 & 4.3 & -- & -- & Medium \\
\hline 12 & Myrsine semiserrata & 29 & 0.5 & 80.35 & 8.4 & Shrub \\
\hline 13 & Persea duthiei & 33.4 & 1.5 & 4.3 & 1.5 & Small \\
\hline 14 & Pyrus pashia & 29.3 & 2.4 & 29.9 & 3.3 & Small \\
\hline 15 & Quercus lanata & 20.4 & 0.3 & 21.5 & 7.9 & Large \\
\hline 16 & Quercus semecarpifolia & -- & -- & 40.3 & 53.2 & Large \\
\hline 17 & Rhododendron arboreum & 34.2 & 38.8 & 36.6 & 66.4 & Small \\
\hline 18 & Rhus succedanea & -- & -- & 2.25 & 0.2 & Small \\
\hline 19 & Schima wallichii & 17.9 & 21.8 & -- & -- & Medium \\
\hline 20 & Stranvaesia nussia & 6.35 & 6.6 & -- & -- & Small \\
\hline 21 & Viburnum erubescens & -- & -- & 16 & 0.4 & Small \\
\hline & 300 & 101.8 & 300 & 153.8 & \\
\hline
\end{tabular}

